\title{
Biogeographic patterns in the cartilaginous fauna (Pisces: Elasmobranchii and Holocephali) in the southeast Pacific Ocean
}

The abundance and species richness of the cartilaginous fish community of the continental shelf and slope off central Chile is described, based on fishery-independent trawl tows made in 2006 and 2007. A total of 194,705 specimens comprising 20 species ( 9 sharks, 10 skates, 1 chimaera) were caught at depths of $100-500 \mathrm{~m}$ along a $1,000 \mathrm{~km}$ transect between $29.5^{\circ}$ $\mathrm{S}$ and $39^{\circ} \mathrm{S}$. Sample site locations were grouped to represent eight geographical zones within this latitudinal range. Species richness fluctuated from 1 to 6 species per zone. There was no significant latitudinal trend for sharks, but skates showed an increased species richness with latitude. Standardised catch per unit effort (CPUE) increased with increasing depth for sharks, but not for skates, but the observed trend for increasing CPUE with latitude was not significant for either sharks or skates. A change in community composition occurred along the depth gradient with the skates, Psammobatis rudis, Zearaja chilensis and Dipturus trachyderma dominating communities between 100 and $300 \mathrm{~m}$, but small-sized, deep-water dogfishes, such as Centroscyllium spp. dominated the catch between 300 and $500 \mathrm{~m}$. Cluster and ordination analysis identified one widespread assemblage, grouping $58 \%$ of sites, and three shallow-water assemblages. Assemblages with low diversity (coldspots) coincided with highly productive fishing grounds for demersal crustaceans and bony fishes. The community distribution suggested that the differences between assemblages may be due to compensatory changes in mesopredator species abundance, as a consequence of continuous and unselective species removal. Distribution patterns and the quantitative assessment of sharks, skates and chimaeras presented here complement extant biogeographic knowledge and further the understanding of deep-water ecosystem dynamics in relation to fishing activity in the south-east Pacific Ocean. 
3 Carlos Bustamante ${ }^{1,2}$, Carolina Vargas-Caro ${ }^{1,2}$, Michael B. Bennett ${ }^{1}$

$4{ }^{1}$ School of Biomedical Sciences, The University of Queensland, St Lucia, Queensland 4072,

5 Australia.

$6 \quad{ }^{2}$ Programa de Conservación de Tiburones (Chile), Valdivia, Chile.

7 Running title: Biogeographic patterns of Chilean cartilaginous fishes

8 Corresponding author: C. Bustamante

9 Telephone: +61733467975

10 E-mail: c.bustamantediaz@uq.edu.au 


\section{Abstract}

The abundance and species richness of the cartilaginous fish community of the continental

13 shelf and slope off central Chile is described, based on fishery-independent trawl tows made in

142006 and 2007. A total of 194,705 specimens comprising 20 species ( 9 sharks, 10 skates, 1

15 chimaera) were caught at depths of $100-500 \mathrm{~m}$ along a $1,000 \mathrm{~km}$ transect between $29.5^{\circ} \mathrm{S}$ and

$1639^{\circ} \mathrm{S}$. Sample site locations were grouped to represent eight geographical zones within this

17 latitudinal range. Species richness fluctuated from 1 to 6 species per zone. There was no

18 significant latitudinal trend for sharks, but skates showed an increased species richness with

19 latitude. Standardised catch per unit effort (CPUE) increased with increasing depth for sharks, but

20 not for skates, but the observed trend for increasing CPUE with latitude was not significant for

21 either sharks or skates. A change in community composition occurred along the depth gradient

22 with the skates, Psammobatis rudis, Zearaja chilensis and Dipturus trachyderma dominating

23 communities between 100 and $300 \mathrm{~m}$, but small-sized, deep-water dogfishes, such as

24 Centroscyllium spp. dominated the catch between 300 and $500 \mathrm{~m}$. Cluster and ordination analysis

25 identified one widespread assemblage, grouping $58 \%$ of sites, and three shallow-water

26 assemblages. Assemblages with low diversity (coldspots) coincided with highly productive

27 fishing grounds for demersal crustaceans and bony fishes. The community distribution suggested

28 that the differences between assemblages may be due to compensatory changes in mesopredator

29 species abundance, as a consequence of continuous and unselective species removal. Distribution

30 patterns and the quantitative assessment of sharks, skates and chimaeras presented here

31 complement extant biogeographic knowledge and further the understanding of deep-water

32 ecosystem dynamics in relation to fishing activity in the south-east Pacific Ocean. 
Cartilaginous fishes play an important role as top predators and have complex distribution patterns (Wetherbee \& Cortés, 2004), affecting the structure and function of marine communities through interactions with other trophic links in food webs to which they belong (Ferretti et al., 2010). Spatial distribution patterns of marine fishes in the south-east Pacific Ocean are poorly understood, and most studies of demersal communities have focused on the ecology of continental shelf fauna at depths of between 20 and 150 m (Brattström \& Johanssen, 1983; Ojeda, 1983; Carrasco, 1997; Ojeda, Labra \& Muñoz, 2000; Camus, 2001; Sellanes, 2007). Descriptions

41 of geographical patterns of marine fishes have been restricted to littoral species (Mann, 1954;

42 Pequeño, Rucabado \& Lloris, 1990), and based on regional inventories (Ojeda, Labra \& Muñoz, 43 2000). A general lack of quantification of species abundance limits our understanding of the 44 functional biodiversity of the continental shelf of Chile (Pequeño, 1989; Bustamante, Vargas45 Caro \& Bennett, 2014).

46 Chile has a cartilaginous fish fauna that is relatively rich when compared with warm-

47 temperate countries in South America (Bustamante, Vargas-Caro \& Bennett, 2014), but poor in 48 the global context despite having one of the largest maritime territories in the world (Cubillos, 49 2005). Species checklists and biological observations constitute the first approaches in the study 50 of the cartilaginous fish fauna in the Chilean marine ecosystem and there are a number of studies 51 that have reported on elasmobranch species around the central and southern continental shelf, 52 from both fishery -dependent and -independent surveys (Meléndez \& Meneses, 1989; Pequeño, 53 1989; Pequeño, Rucabado \& Lloris, 1990; Pequeño \& Lamilla, 1993). In northern Chile, bycatch

54 analysis of the crustacean trawl fishery has contributed to knowledge of the continental slope 55 ecosystem through the description of biological diversity, composition and structure of the 56 demersal fish fauna over a wide depth range (Sielfeld \& Vargas, 1999; Acuña et al., 2005; 
57 Menares \& Sepúlveda, 2005). While fishery-dependent studies offer a description of diversity

58 and species assemblages of cartilaginous fishes, using catch per unit effort (CPUE) as a proxy for

59 abundance (Acuña et al., 2005), they generally lack the ability to adequately identify or provide

60 quantitative information on species richness, abundance hotspots and conspecific assemblages

61 that are required for a better understanding of marine ecosystem interrelationships (Kyne \&

62 Simpfendorfer, 2007).

63 The aim of the present study is to analyse abundance and species richness of cartilaginous

64 fishes of the continental shelf and slope in Chile to identify patterns in the geographical and

65 bathymetric distribution of sharks, skates and chimaeras in the south-east Pacific Ocean to 66 complement existing biogeographic models, and improve the understanding of deep-water 67 ecosystem dynamics in the context of fishing activities.

\section{Material and Methods}

Data were collected through direct observation of total catch on fishery-independent 70 surveys made along the Chilean continental slope and shelf as part of a broader project to assess

71 the biological and oceanographical characteristics of the Chilean seafloor (Melo et al., 2007).

72 Surveys were carried out on-board two fishing vessels, "Crusoe I" and "Lonquimay", equipped as

73 oceanographic research platforms. Fishing gear comprised a bottom trawl constructed from $3 \mathrm{~mm}$

74 diameter polyamide nylon with $50 \mathrm{~mm}$ stretch-measured diamond-mesh in the tunnel and cod-

75 end. The trawl had a $24 \mathrm{~m}$ headrope, a $28 \mathrm{~m}$ footrope, and a stretched circumference of $34 \mathrm{~m}$ with

76 an average net opening during tows of $11 \mathrm{~m}$. Tows lasted $18-53 \mathrm{~min}$ at a speed of $3.7 \mathrm{~km} \mathrm{~h}^{-1}$

77 which resulted in a swept area of $12.2-35.9 \mathrm{~km}^{2}$. Geometric construction of fishing gear and tow

78 speed were used to calculate CPUE which was standardised as individuals per hour and square 
79 kilometre swept (ind $\mathrm{km}^{-2} \mathrm{~h}^{-1}$ ). For each species, CPUE data were calculated separately and log80 transformed $(\log (\mathrm{CPUE}+1))$ in order to assess the departure of original data from normality.

81 Geographic coordinates and depth of each trawl were recorded for each tow.

82 A total of 128 tows were made in 32 sites grouped in eight regions, numbered from north 83 to south as zones 1 to 8 , that span approximately $1,000 \mathrm{~km}$ between the latitudes $29.5^{\circ} \mathrm{S}$ and $39^{\circ}$

84 S (Fig. 1). Survey data were collected from sites in four depth strata (labelled as A: $100-199 \mathrm{~m}$, 85 B: $200-299 \mathrm{~m}, \mathrm{C}: 300-399 \mathrm{~m}$ and D: $400-499 \mathrm{~m}$ ) with four pseudoreplica tows in each site 86 (16 tows per zone with 4 tows per site). Zones 1, 2, 4 and 5 were sampled in July/August 2006, 87 zones 6, 7 and 8 in November/December 2006, and zone 3 was sampled twice, in July 2006 and 88 again in March 2007. Each site was recorded and coded with the zone (1 to 8), depth strata (A to 89 D) and pseudoreplica tow (numbered 1 to 4), i.e., tow coded as "1.A.2" represents the second tow 90 made in zone 1 , between $100-199 \mathrm{~m}$ depth.

91 This study was carried out in accordance with the "standards for the use of animals in

92 research" approved by the Animal Care and Ethics Committee of the Universidad Austral de

93 Chile (UACH/FIP 2005-61). Capture of fishes during this study was permitted through Fisheries

94 Undersecretariat Research Permit Number 1959-06, 2931-06 and 181-07 issued by Ministry of 95 Economy, Development and Tourism.

\section{Community definition}

All cartilaginous fishes captured during surveys were counted and identified to species. A number of individuals caught $(\sim 1 \%)$ were landed frozen to validate on-board identification using diagnostic features described in literature (Compagno, 1984a; Compagno, 1984b; Lamilla \& Sáez, 2003; Lamilla \& Bustamante, 2005; Ebert, Fowler \& Compagno, 2013). Species diversity was calculated from the number of species at each tow; and compared using the Shannon diversity index ( $H$ according to Spellerberg \& Fedor, 2003) by depth and zone. 
104 number of species within a specific number of individuals sampled (Kempton, 1979). Relative

105 frequency of occurrence $\left(F_{\mathrm{O}}\right)$ was determined for each species to explore the variability of

106 species' occurrence along bathymetric and latitudinal gradients; and is expressed as a percentage

107 of occurrence of a species in relation to the total number of tows within sites and zones. Three

108 categories of $F_{\mathrm{O}}$ were determined according to Solervicens (1973): Regular species, where $F_{\mathrm{O}}=$

$109>50 \%$; Accessory species, where $F_{\mathrm{O}}=25-49 \%$ and; Incidental species, where $F_{\mathrm{O}}=10-24 \%$.

110 Latitudinal and bathymetric gradients of species diversity of the major taxonomic groups (sharks

111 and skates) were compared using analysis of covariance (ANCOVA) with significance accepted

112 at $P<0.05$.

\section{Community structure}

114 Faunal assemblages and geographic patterns of cartilaginous fishes were determined

115 through a global similarity matrix. Species composition and abundance in each tow were

116 considered for the entire study area with CPUE values fourth-root transformed to balance outliers

117 (rare and abundant species). Sampling sites were sorted by an agglomerative hierarchical cluster

118 and through non-dimensional metric scaling (nMDS) considering the global similarity matrix

119 (Clarke, 1993; Clarke \& Warwick, 1994). Log-transformed CPUE values were used for

120 hierarchical agglomerative clustering with group-averaging linking, based on the Bray-Curtis

121 similarity measure to delineate groupings with a distinct community structure. A one-way

122 ANOSIM was used to establish possible differences between sampling site groups. Additionally,

123 a SIMPER analysis was used to determine the contribution of each species to the average Bray-

124 Curtis dissimilarity between groups. All indices and statistical procedures were made using

125 software PRIMER v.6.0 (Plymouth Marine Lab, Plymouth, UK). 
From 32 sites sampled, the total catch was 194,705 cartilaginous fishes from the 76

128 towsthat contained specimens, of which 2,725 individuals were landed and examined. In 52 tows

$129(40.6 \%$ of the total $)$ there was no catch of cartilaginous fishes and were thus excluded from the 130 remaining analysis. A total of 20 species (nine sharks, ten skates and one chimaera) was 131 confirmed (Table 1). Note, that for the purpose of the current study the term 'skate' includes 132 Torpedo tremens. Bathymetrically, the shallowest depth stratum $(100-199 \mathrm{~m})$ and latitudinally, 133 the northernmost zone (zone 1) yielded the lowest percentage occurrence of cartilaginous fishes 134 caught in $3.13 \%$ and $37.5 \%$ of tows respectively (Table 2). The greatest number of species caught 135 per family was five, in the family Arhynchobatidae, followed by the families Rajidae (four 136 species), Etmopteridae and Scyliorhinidae (both three species). The Hexanchidae, Somniosidae, 137 Centrophoridae, Torpedinidae and Chimaeridae were each represented by a single species (Table $1381)$.

\section{Community definition}

140 Species richness fluctuated between one and six species per site with no significant

141 differences between sharks and skates in slopes of the regression $($ ANCOVA; $F=0.826 ; \mathrm{df}=1$,

$142117 ; P=0.365$; Fig. 2), but there were significant differences in the intercepts (ANCOVA; F = $14324.972 ; \mathrm{df}=1,117 ; P>0.001)$. There was no significant relationship between species richness 144 and latitude for sharks, but species richness for skates increased with increasing latitude (Fig. 2A, 145 C). Chimaeras were absent in the catch from zones 6 and 8, but occurred in the other six zones 146 (Fig. 2E). Species richness increased significantly with depth for sharks, but not for skates (Fig.

$1472 \mathrm{~B}, \mathrm{D})$. The slopes and intercepts of the regressions were significantly different (ANCOVA, F = 148 17.06; $\mathrm{df}=1,117 ; P>0.001$ and $\mathrm{F}=13.954 ; \mathrm{df}=1,117 ; P>0.001$, respectively). Chimaeras 
149 were restricted to 430 - $480 \mathrm{~m}$ within the deepest depth stratum, and were observed off most of 150 the central coast of Chile, between approximately $29.5^{\circ}$ and $37.5^{\circ} \mathrm{S}$ (Fig 2E, F).

151 The CPUE per site ranged widely, from $5.5-2,785$ ind $\mathrm{km}^{-2} \mathrm{~h}^{-1}$ among individual sites and $152728-7,942$ ind $\mathrm{km}^{-2} \mathrm{~h}^{-1}$ among zones (Table 3). Log-transformed CPUE increased with latitude 153 for both sharks and skates, although the slopes of the regressions were not significantly different 154 (Fig. 3A, C). Based on latitude, the ANCOVA did not reveal significant differences in slope $(\mathrm{F}=$ $1550.412 ; \mathrm{df}=1,117 ; P=0.523)$, but did in elevation between sharks and skates $(\mathrm{F}=43.942 ; \mathrm{df}=1$, 156 117; $P>0.001)$. There was a significant effect of depth on the CPUE for sharks, but not for 157 skates (Fig 3B, D), and there was a significant difference between the slopes and elevations of the 158 regressions $($ ANCOVA $; \mathrm{F}=19.59 ; \mathrm{df}=1,117 ; P>0.001 ; \mathrm{F}=31.12 ; \mathrm{df}=1,117 ; P>0.001$, 159 respectively). For chimeras, the CPUE was generally low across the species' latitudinal range 160 (Fig. 3E).

161 Diversity index $(H)$ was not influenced by latitude for sharks, but increased significantly 162 for skates (Fig. 4; ANCOVA; F = 5.056; df $=1,117 ; P=0.263$ ) and the intercepts were 163 significantly different (ANCOVA; $\mathrm{F}=15.92 ; \mathrm{df}=1,117 ; P>0.0001$ ). Values of $H$ for sharks 164 averaged approximately 0.6 across the eight zones, but showed high variability among sites in 165 each zone (Fig 4A). For skates, there were zero-values for $H$ in all zones, particularly zone 1, but 166 values of up to approximately 1.1 also occurred at sites in the central and southern zones (Fig. 167 4C). Significant differences were observed in the slopes and intercepts of the regression between 168 sharks and skates based on depth $($ ANCOVA; $\mathrm{F}=15.35 ; \mathrm{df}=1,117 ; P>0.001$ and $\mathrm{F}=8.40 ; \mathrm{df}=$ $1691,117 ; P>0.001)$. Diversity index for sharks was markedly higher in waters over about $325 \mathrm{~m}$ 170 deep, and was almost absent in shallowed depth strata (Fig. 4B). Skate diversity varied 171 considerably within most depth strata and, overall, showed no significant trend with depth (Fig. 172 4D). 
174 and two regular species (Psammobatis rudis, Zearaja chilensis), represent the community at 200

$175-299 \mathrm{~m}$ depth. Hexanchus griseous and T. tremens are regular species, along with six accessory

176 species in the $300-399 \mathrm{~m}$ depth stratum. Hexanchus griseus was restricted to this stratum,

177 whereas T. tremens was also captured at shallower depths. Centroscymnus macracanthus, 178 Apristurus nasutus, Bathyraja peruana, Bathyraja albomaculata, Rajella sadowskii and 179 Hydrolagus macrophthalmus were only found in the deepest stratum $(400-499 \mathrm{~m})$, whereas 180 there were nine other regular species that were also represented in shallower strata (Table 5).

181 A taxonomic change in community composition occurred along the depth gradient. Three

182 skates, Psammobatis rudis, Zearaja chilensis and Dipturus trachyderma dominated communities 183 between 100 and $300 \mathrm{~m}$ accounting for $>80 \%$ of total cartilaginous fish CPUE, but as depth 184 increased there was a major shift in community, as small-sized, deep-water dogfishes, such as 185 Centroscyllium spp. came to dominate the catch (Fig. 3, Table 4). Other contributors to this 186 species-complex change were relative reductions in Bythaelurus canescens and small-sized 187 skates (i.e., Psammobatis rudis and Gurgesiella furvescens) (Table 4, 5).

188 Community structure

189 Agglomerative hierarchical cluster analysis (Fig. 5) revealed four major fish assemblages 190 (I - IV) at similarity level of 40\%, and one outlier. The ANOSIM showed that the four 191 assemblages were significantly separated from each other $(\mathrm{n}=76, \mathrm{R}$ Global $=0.68 ; P>0.01)$, 192 with the outlier characterised by presence of one single species (Bathyraja peruana) with the 193 lowest total CPUE (8.6 ind $\mathrm{km}^{-2} \mathrm{~h}^{-1}$ ). Geographically, assemblage I grouped 11 sites located north 194 of Coquimbo to Valparaíso (zones 1 - 3, Fig. 1) and between depths of 237 to 379 m, with an 195 average of CPUE of 56.3 ind $\mathrm{km}^{-2} \mathrm{~h}^{-1}$ for 10 species ( 5 sharks and 5 skates). This community was 196 dominated by Centroscyllium nigrum that comprised $34.3 \%$ of the CPUE, Bythaelurus canescens 
197

198

199

200

201

202

203

204

205

206

207

208

209

210

211

212

213

214

215

216

217

218

219

220

(22.2\% CPUE) and Psammobatis rudis (11.5\% CPUE) (Table 5). Assemblage II included the largest number of sites (45), taxa (20) and specimens (average CPUE $=475$ ind $\mathrm{km}^{-2} \mathrm{~h}^{-1}$ ). Sites in this assemblage were scattered over the entire study area and occupied a depth range of $335-492$ m. Prominent species in this assemblage were C. granulatum (37.6\% CPUE), C. nigrum (28.5\% CPUE), and B. canescens (15.9\% CPUE) (Table 5). Assemblage III comprised 10 relatively shallow sites $(149-262 \mathrm{~m})$ in the most southerly zone offshore from Concepción, the second largest port in Chile. The skates Z. chilensis and D. trachyderma dominated this assemblage of 6 species with $83.3 \%$ of the assemblage CPUE (158 ind $\mathrm{km}^{-2} \mathrm{~h}^{-1}$; Table 5). Assemblage IV grouped 10 relatively shallow sites $(243-281 \mathrm{~m})$ located south of Valparaíso in zones 4,5 and 6 . This assemblage had the lowest diversity ( 5 species) and abundance (39.9 ind $\left.\mathrm{km}^{-2} \mathrm{~h}^{-1}\right)$. Two species, Psammobatis rudis and C. granulatum, were the most abundant species accounting for $63.4 \%$ and $20.4 \%$ of CPUE respectively (Table 6).

Ordination analysis (nMDS) produced similar results to cluster analysis with four assemblages (Fig. 6). The outlier observed (zone 3, site B, tow 1) was a tow off Valparaíso apparently separated from other tows due to the presence of a single species (Bathyraja peruana) with low abundance $\left(8.5\right.$ ind $\left.\mathrm{km}^{-2} \mathrm{~h}^{-1}\right)$. SIMPER analysis showed low average within-assemblage similarity of $29.9-38.6 \%$ for all assemblages. Two main consolidating species, $P$. rudis and $D$. trachyderma were identified within each assemblage, and accounted for $100 \%$ within-assemblage similarity in assemblage III; $59.4 \%$ in assemblage IV and $>6 \%$ in assemblages I and II, respectively. Unlike within-assemblage similarity, the between-assemblage dissimilarity levels in all four assemblages were high, ranging from 92.7 to $96.7 \%$. Psammobatis rudis, Bythaelurus canescens, Centroscyllium nigrum and Dipturus trachyderma, accounted for $80.7 \%$ of total $(84.2 \%)$ dissimilarity between assemblages I and III. Nine species together contributed $92.9 \%$ towards total (96.7\%) dissimilarity between assemblages I and II. Eight species were responsible 221 for $91.9 \%(95.1 \%)$ and $90.5 \%(94.3 \%)$ of total dissimilarity in both, assemblages II and III and 
222

223 dissimilarity between assemblages II and III; while between assemblages III and IV, Zearaja 224 chilensis, Dipturus trachyderma, Psammobatis rudis and Centroscyllium granulatum accounted 225 for $91.9 \%$ of total $(92.7 \%)$ dissimilarity.

\section{Discussion}

Trawling has long been used to explore waters off the central-north and central-south

assemblages II and IV respectively. Finally, seven species contributed 92\% towards total (93.4\%)

coasts of Chile in order to identify regions where benthic crustaceans and teleost fishes of commercial interest occur in high abundance (Sielfeld \& Vargas, 1996; Menares \& Sepulveda, 2005). Currently, trawl-fishing effort is centred, but not restricted, on squat lobsters (Cervimunida johni and Pleuroncodes monodon), deep-water shrimps (Heretocarpus reedi), hakes (Merluccius gayi and M. australis) and Chilean horse mackerel (Trachurus murphyi). The abundance of these target species is estimated through regular trawl surveys to allow the fishing effort to be adjusted to achieve 'maximum sustainable yield'. A useful by-product of such surveys has been the production of species checklists that have enriched knowledge of Chile's national marine biodiversity (Pequeño, 2000; Acuña et al., 2005). These extensive fishery-dependent and independent surveys, that include cartilaginous fishes in the catch, are conducted annually in central Chilean waters (c. $21.5-38.5^{\circ}$ S). For example, between 1994 and 2004, exploratory surveys for demersal crustaceans comprised 6,143 trawl hauls made at depths of $100-500 \mathrm{~m}$ (Acuña et al., 2005). Although 13 shark, 8 skate and 1 chimaera species were caught, published data are limited to a simple indication of the latitudinal range for each species (Acuña et al., 2005). The absence of quantitative data on the species' abundance, particularly in respect of fishing effort, location (latitude) and depth provides a challenge for management, whether for exploitation or for conservation. It is also of relevance to note that these fishery-dependent and 
245 independent surveys report on the diversity of animals from areas that are subject to continuous

246 and often intense fishing activity which is implicated in the decline in species richness (Wolff \& 247 Aroca, 1995).

248 There has also been a number of fishing-independent studies, such as Ojeda (1983), that 249 reported the presence of 2 shark and 3 skate species from 118 hauls made at depths of over $500 \mathrm{~m}$ 250 on a trawl survey in austral Chile $\left(52^{\circ} \mathrm{S}-57^{\circ} \mathrm{S}\right)$. Further north, 133 hauls made between $31^{\circ} \mathrm{S}-$ $25141^{\circ} 28^{\prime} \mathrm{S}$ at depths of $50-550$ m produced 7 shark, 5 skate and 1 chimaera species (Menares \& 252 Sepúlveda, 2005). In central Chile, Meléndez \& Meneses (1989) reported 11 shark species from 253173 hauls in exploration surveys using bottom trawl nets between $18^{\circ} \mathrm{S}-38^{\circ} 30^{\prime} \mathrm{S}$ and at depths 254 of $500-1260 \mathrm{~m}$. In the most northerly survey, between $18^{\circ} \mathrm{S}$ and $21^{\circ} \mathrm{S}$, the same gear type used 255 over a wider depth range $(30-1050 \mathrm{~m})$ resulted in 4 shark, 4 skate and 1 chimaera species from

25621 hauls (Sielfeld \& Vargas, 1996). Each of these studies, however, also lacked quantification of 257 the catch and are therefore of limited value, beyond providing information on the presence (or 258 apparent absence) of species within a geographic region.

\section{Community definition}

260 The species richness observed in the current study (20 species), is higher than those found 261 in surveys conducted previously in the region (Ojeda, 1983; Meléndez \& Meneses, 1989; Sielfeld

262 \& Vargas, 1996; Ojeda, Labra \& Muñoz, 2000; Acuña \& Villarroel, 2002; Acuña et al., 2005; 263 Menares \& Sepulveda, 2005). Variation in the reported species richness of cartilaginous fishes 264 within the region among years may reflect the different gear types used, different effort, different 265 depths sampled, and species misidentifications (Pequeño \& Lamilla, 1993; Lamilla et al., 2010). 266 While the species richness reported here is similar to that reported by Acuña et al. (2005), the 267 cartilaginous fish community appears to differ between the two studies. Direct comparisons are 268 somewhat speculative as while our study provides quantification of the fauna in terms of CPUE 
and $F_{\mathrm{O}}$ while the results of Acuña et al. (2005) are limited to whether a species was present, in

270 unreported abundance. Nevertheless, a couple of thematic differences are apparent with small,

271 shallow-water skates (i.e., Psammobatis scobina, Sympterygia lima, S. brevicaudata and

272 Discopyge tschudii) absent in our study, while deep-sea skates of the genera Bathyraja and

273 Rajella were not caught in the earlier study (Fig. 7). These results suggest that, in comparison to

274 our study, (a) shallower waters may have been sampled, and (b) the fishing effort in deeper

275 waters was more limited in the study reported by Acuña et al. (2005). Taken together, these two

276 studies indicate that at least 30 cartilaginous fishes inhabit (or did inhabit) the continental shelf

277 and slope off central Chile; although some species showed pronounced latitudinal variation in 278 distribution (e.g. Aculeola nigra, Centroscyllium nigrum, Gurgesiella furvescens) while in some

279 others, the latitudinal extension is not reported (i.e., Bathyraja peruana, Sympterygia 280 brevicaudata, S. lima, Discopyge tschudii).

281 Species abundance was highly variable between zones with the lowest abundance in the

282 north (zone 1). The abundance in the central and the most southern zones $(2,3,4$ and 8$)$ was 283 about double this value, in zones 5 and 7 it was four times as large and in zone 6 it was an order 284 of magnitude greater. Interestingly, five species (e.g., Hexanchus griseus, Centroscymnus 285 macracanthus, Bathyraja brachyurops, B. multispinis, Rajella sadowskii) were caught, mostly in 286 low numbers, only within a single zone and within a single depth stratum. The pattern of 287 occurrence suggests that the species are naturally uncommon or, more likely, that the trawl 288 regime only sampled the upper end of their natural range (Fig. 7). In contrast, two species (e.g., 289 Apristurus nasutus and Hydrolagus macrophthalmus) showed a marked preference for a 290 particular depth stratum but occurred in more than one zone. Others species showed an obvious 291 latitudinal variation in abundance, for example, Aculeola nigra was common in the north (zones $2921-4)$, rare in central zones $(5-6)$ and absent in the southern zones $(7-8)$; whereas, 293 Psammobatis rudis and Dipturus trachyderma showed the opposite trend. Both Centroscyllium 
294 species (C. granulatum and C. nigrum) have a high abundance in central Chile and are less

295 common in both north and south, and appear to become extremely abundant with increasing

296 depth. Between 300 and $500 \mathrm{~m}$, the diversity further doubled and the abundance of most species

297 increased. With the exception of two species (Zearaja chilensis and Torpedo tremens), all

298 cartilaginous fishes were caught at depths below $200 \mathrm{~m}$ and most increase their abundance with

299 depth. This relative absence of cartilaginous fishes in shallow waters $(100-199 \mathrm{~m})$ was both

300 unexpected and difficult to explain, and needs to be addressed in future studies.

\section{Community structure}

302 Species richness of cartilaginous fishes in the south-east Pacific has been described to

303 increase towards lower latitudes following the same geographic pattern of other marine fishes

304 (Meléndez \& Meneses, 1989; Pequeño, Rucabado \& Lloris, 1990; Rohde, 1992; Pequeño \&

305 Lamilla, 1993; Camus, 2001); however, these observations are based on species inventories

306 without reference to latitudinal or bathymetric ranges which obviously can have a marked

307 influence on species distributions. Also, elasmobranch diversity in the Atlantic and Pacific oceans

308 have been described to decrease with depth, especially below 1,000 m depth (Pakhomov et al.,

309 2006; Priede et al., 2006). Our results provided evidence of an overall increase in species richness

310 with increasing latitude and depth down to $500 \mathrm{~m}$, in contrast to a decrease in diversity with

311 increasing latitude demonstrated by littoral fishes (Ojeda, Labra \& Muñoz, 2000), but similar to

312 diversity gradients of benthic invertebrates and in the Northern Hemisphere described by Rex et

313 al. (2000). In our study, the latitudinal and bathymetric stability of assemblage II (Fig. 5), is

314 consistent with a "transition intermediate area" as described by Camus (2001), and suggests that

315 differences between assemblages were due to compensatory changes in mesopredator abundance

316 (Navia et al., 2011). There is a correlation between the location of assemblages I, III and IV and

317 intensive trawl fishing areas (Wolff \& Aroca, 1995; Escribano, Fernandez \& Aranis, 2003; Acuña 
318 et al., 2005). Continuous and unselective removal of certain species by commercial fisheries may

319 explain in part the variation of species abundance among assemblages.

320 At the community level, the main assemblage (II) was distributed across the entire

321 surveyed area comprising 58\% of sites; and showed a high average dissimilarity to assemblages I,

322 III and IV $(96.7,95.1$ and $94.3 \%$ respectively). Differences were mainly due to the importance of

323 small-sized sharks (Bythaelurus canescens, Centroscyllium granulatum and C. nigrum), although

324 diversity of small-sized skates also contributed to overall dissimilarity. In our study assemblages

325 I, III and IV represented 'coldspots' of diversity, similar to those found along the outer shelf in

326 south-west Atlantic cartilaginous fish community (Lucifora et al. 2011). While those coldspots

327 were simply defined as areas of low diversity, in the current study coldspots coincide with

328 traditional fishing grounds. Commercial fisheries in Chile, in particular trawl-based activities, are

329 likely to have a direct effect on cartilaginous fish community structure and distribution as has

330 been previously documented for other marine fishes in central Chile (Arancibia \& Neira, 2005).

331 Different levels of fishing pressure can generate multiple effects on the function of species

332 and their interactions (Navia et al., 2011). High species richness and abundance represented in

333 assemblage II, is consistent with a more stable community as high biodiversity has been linked to

334 the stability of trophic networks through the complex interactions that arise among its

335 components (Navia et al., 2011). In contrast, when there is an external disturbance, in this case

336 differential exposure to fishing pressure, the result may be a complete reorganisation of the

337 community (Bascompte, Melián \& Sala, 2005).

338 Considering the overall species composition without counting rare species (defined in

339 relation to low species abundance), such as Echinorhinus cookei and Centroscymnus owstonii, the

340 absence of mid- to large-sized sharks is evident in our study (Fig. 7), however fishing gear

341 selectivity and species catchability may influence the frequency of occurrence observed. Ferretti

342 et al. (2010) described the ecological restructuring of demersal elasmobranch communities in 
343 fishing areas worldwide. Diversity and abundance of elasmobranchs erodes quickly as fisheries

344 remove, unselectively, both small and large species despite the lower catchability of the latter. As

345 large sharks disappear from the catch as fisheries develop, the community tends to become

346 dominated by mesopredators. In the current study these mesopredators are predominantly small-

347 sized sharks, which are more fecund and more resilient to fishing pressures than other

348 elasmobranchs. Examples of similar community restructuring have been documented for trawl

349 fishing areas in the Atlantic (Ellis et al., 2005), Gulf of Mexico (Shepherd \& Myers, 2005), the

350 Mediterranean Sea (Ferretti et al., 2008) and Australian waters (Graham, Andrew \& Hodgson,

351 2001); although its extension to similar trawl fisheries elsewhere has not been properly evaluated

352 due to a lack of temporal and seasonal catch-composition data for elasmobranch species.

\section{Limitations and future directions}

354 Previous research has identified two distinct biogeographic provinces based on multiple

355 taxa along the Chilean coast, the Peruvian province in the north $\left(4^{\circ}-30^{\circ} \mathrm{S}\right)$ and the Magellanic

356 province in the south $\left(42^{\circ}-56^{\circ} \mathrm{S}\right)$ (Camus, 2001). There is also an "intermediate area" between

357 these two provinces that has been described as a rich, mixed-origin species' transition zone for

358 teleost fishes (Pequeño, 2000; Ojeda, Labra \& Muñoz, 2000). Considering the limitations of

359 geographic scale, the single main biogeographic province (assemblage II) that was identified

360 between $29.5^{\circ} \mathrm{S}$ and $38.5^{\circ} \mathrm{S}$ only showed limited evidence of species more usually associated

361 with the Peruvian and Magellanic provinces.

362 Fishery-independent surveys allowed us to explore an extensive area, including traditional

363 commercial trawling zones and non-traditional fishing zones with similar effort. It should be

364 mentioned that the methodology used was designed to sample demersal and bottom-dwelling

365 species, and therefore the cartilaginous fish community' definitions used here effectively

366 excludes species that occur in mid- to surface waters and likely underestimates species richness 
367 (Pakhomov et al., 2006). Potential limitations of our analysis include differential vulnerability to

368 fishing gear, which could be species-specific or relate to swimming performance or the size of

369 individuals. The original experimental design attempted to cover all zones during the same

370 season but some were sampled in separated cruises during summer and winter due logistical

371 issues. Oceanographic variability may influence species distribution and potential seasonal

372 changes of abundance and species richness need to be addressed in future research, especially at

373 shallower depths (100 to $200 \mathrm{~m}$ ). Also, the sampling effort was not evenly distributed throughout

374 the whole of the latitudinal range with sites clustered within each zone; as such it is unlikely that

375 all habitat types were sampled. This may be important as rocky substrates and other irregular

376 habitats such as coral reefs and seamounts have been described as high diversity areas (hotspots),

377 especially for cartilaginous fishes (Henry et al., 2013).

378 The clusters of sample sites also resulted in a relatively low resolution 'picture', and 379 precluded a fine scale description of species' distributions and abundance, and how these might 380 be influenced by local conditions (e.g., habitat type).

381 Our results provide a quantitative description of species richness and abundance of the 382 cartilaginous fish community on the outer continental shelf and slope of Chile to complement and 383 extend knowledge of biological and ecological interactions of this demersal ecosystem. More 384 than $90 \%$ of elasmobranch species worldwide inhabit demersal ecosystems on continental shelves 385 and slopes (Compagno, 1990), which makes them vulnerable to trawl fishing (Shepherd \& 386 Myers, 2005) and we are just beginning to understand the potential ecological consequences of 387 removal and declines of cartilaginous fishes. The information presented here is of immediate 388 value in the assessment of the conservation status of species and the threats to their populations 389 posed by demersal trawling. This study is also of particular value for future assessment of how 390 natural or anthropogenic activities may impact the various species by providing quantitative 391 baseline information against which change can be assessed. 


\section{Acknowledgements}

393 The authors wish to thank all researchers involved during the project, especially to the staff of 394 TecPes (Laboratorio de Tecnología Pesquera) at Pontificia Universidad Católica de Valparaíso (T. 395 Melo, C.F. Hurtado, D. Queirolo, E. Gaete, I. Montenegro and R. Escobar). Additional thanks to 396 members of "Programa de Conservación de Tiburones, Chile" and ELASMOLAB staff at 397 Universidad Austral de Chile for their valuable help with logistics, sampling and dissections help 398 during fieldwork, especially J. Lamilla, F. Concha, H. Flores, Y. Concha-Perez and A. Isla. C.B. 399 and C.V. were supported by CONICYT-Becas Chile and TUAP-Graduate School of The 400 University of Queensland.

\section{References}

402 Acuña E, Villarroel JC. 2002. Bycatch of sharks and rays in the deep sea crustacean fishery off 403 the Chilean coast. Shark News 14:16-18. Available at http://www.flmnh.ufl.edu/fish/ 404 organizations/ssg/sharknews/sn14/shark14news15.htm (accessed 25 February 2014).

405 Acuña E, Villarroel JC, Cortés A, Andrade M. 2005. Fauna Acompañante en Pesquerías de 406 Arrastre de Crustáceos de Chile: Implicancias y Desafíos desde la perspectiva de la 407 Biodiversidad. In: Figueroa E, ed. Biodiversidad Marina: Valoración, Usos y Perspectivas. 408 Santiago de Chile: Editorial Universitaria, 395-425.

409 Arancibia H, Neira S. 2005. Long-term changes in the mean trophic level of Central Chile fishery $410 \quad$ landings. Scientia Marina 69:295-300. 
411 Bascompte J, Melián CJ, Sala E. 2005. Interaction strength combinations and the overfishing of a 412 marine food web. Proceedings of the National Academy of Sciences of the United States of 413 America 102:5443-5447 DOI 10.1073/pnas.0501562102.

414 Brattström H, Johanssen A. 1983. Ecological and regional zoogeography of the marine benthic 415 fauna of Chile. Sarsia 68:289-339 DOI 10.1080/00364827.1983.10420583

416 Bustamante C, Vargas-Caro C, Bennett MB. 2014. Not all fish are equal: Which species best 417 represent the functional diversity of a nation's cartilaginous fishes? Using Chile as a case study. 418 Journal of Fish Biology (in press).

419 Camus PA. 2001. Marine biogeography of continental Chile. Revista Chilena de Historia Natural $420 \quad 74: 587-617$.

421 Carrasco FD. 1997. Sublittoral macrobenthic fauna off Punta Coloso, Antofagasta, northern 422 Chile: high persistence of the polychaete assemblage. Bulletin of Marine Science 60:443-459. 423 Clarke KR. 1993. Non-parametric multivariate analyses of changes in community structure. 424 Australian Journal of Ecology 18:117-143 DOI 10.1111/j.1442-9993.1993.tb00438.x

425 Clarke KR, Warwick RM. 1994. Change in marine communities: an approach to statistical 426 analysis and interpretation. Plymouth, UK: Plymouth Marine Laboratory.

427 Compagno LJV. 1984a. Sharks of the World. An Annotated and Illustrated Catalogue of Shark 428 Species Known to Date. FAO Species Catalogue. Vol. 4, Part 1. FAO Fisheries Synopsis, 125. 429 Rome: FAO.

430 Compagno LJV. 1984b. Sharks of the World. An Annotated and Illustrated Catalogue of Shark 431 Species Known to Date. FAO Species Catalogue. Vol. 4, Part 2. FAO Fisheries Synopsis, 125. 432 Rome: FAO.

433 Compagno LJV. 1990. Alternative life-history styles of cartilaginous fishes in time and space. 434 Environmental Biology of Fishes 28:33-75 DOI: 10.1007/BF00751027 
435 Cubillos L. 2005. Diagnóstico, Aspectos Críticos y Propuesta de Sustentabilidad para las 436 Pesquerías Nacionales. In: Figueroa E, ed. Biodiversidad Marina: Valoración, Usos y 437 Perspectivas. Santiago de Chile: Editorial Universitaria, 27-46.

438 Ebert DA, Fowler S, Compagno LVJ. 2013. Sharks of the World. Plymouth: Wild Nature Press.

439 Ellis JR, Cruz-Martinez A, Rackham B, Rogers SI. 2005. The distribution of chondrichthyan 440 fishes around the British Isles and implications for conservation. Journal of Northwest Atlantic 441 Fishery Science 35:195-213 DOI 10.2960/J.v35.m485

442 Escribano R, Fernandez M, Aranis A. 2003. Physical-chemical processes and patterns of diversity 443 of the Chilean eastern boundary pelagic and benthic marine ecosystems: An overview. Gayana $444 \quad 67: 190-205$.

445 Ferretti F, Myers RA, Serena F, Lotze HK. 2008. Loss of large predatory sharks from the 446 Mediterranean Sea. Conservation Biology 22:952-64 DOI 10.1111/j.1523-1739.2008.00938.x

447 Ferretti F, Worm B, Britten GL, Heithaus MR, Lotze HK. 2010. Patterns and ecosystem 448 consequences of shark declines in the ocean. Ecology Letters 13:1055-1071 DOI $449 \quad 10.1111 / \mathrm{j} .1461-0248.2010 .01489 . x$

450 Graham KJ, Andrew NL, Hodgson K. 2001. Changes in relative abundance of sharks and rays on 451 Australian south east fishery trawl grounds after twenty years of fishing. Marine \& Freshwater 452 Research 52: 549-61 DOI 10.1071/MF99174

453 Henry LA, Navas JM, Hennige SJ, Wicks LC, Vad J, Roberts JM. 2013. Cold-water coral reef 454 habitats benefit recreationally valuable sharks. Biological Conservation 161:67-70 DOI $455 \quad$ 10.1016/j.biocon.2013.03.002

456 Kempton RA. 1979. The Structure of Species Abundance and Measurement of Diversity. 457 Biometrics 35:307-321.

458 Kyne PM, Simpfendorfer CA. 2007. A collation and summarization of available data on 459 deepwater Chondrichthyans: biodiversity, life history and fisheries. IUCN Shark Specialist 
461 (accessed 25 February 2014).

462 Lamilla J, Sáez S. 2003. Taxonomic key for the identification of Chilean rays and skates species

463 (Chondrichthyes, Batoidei). Investigaciones Marinas, Valparaíso 31:3-16 DOI 10.4067/S0717-

46471782003000200001.

465 Lamilla J, Bustamante C. 2005. Guía para el reconocimiento de tiburones, rayas y quimeras de 466 Chile. Oceana 18:1-80.

467 Lamilla J, Bustamante C, Roa R, Acuña E, Concha F, Melendez R, López S, Aedo G, Flores H, 468 Vargas-Caro C. 2010. Estimación del descarte de condrictios en pesquerías artesanales (Informe 469 Final FIP 2008-60). Valdivia: Universidad Austral de Chile. Available at 470 http://www.fip.cl/Proyectos.aspx (accessed 25 February 2014).

471 Lucifora LO, García VB, Menni RC, Worm B. 2011. Spatial patterns in the diversity of sharks, 472 rays, and chimaeras (Chondrichthyes) in the Southwest Atlantic. Biodiversity and Conservation 473 21:407-419 DOI 10.1007/s10531-011-0189-7

474 Mann G. 1954. La vida de los peces en aguas chilenas. Santiago: Instituto de Investigaciones 475 Veterinarias y Universidad de Chile.

476 Meléndez R, Meneses D. 1989. Tiburones del talud continental recolectados entre Arica (18 $19^{\circ}$ 'S) 477 e Isla Mocha (38³0'S), Chile. Investigaciones Marinas, Valparaíso 17: 3-73.

478 Melo T, Silva N, Muñoz P, Díaz-Naveas J, Sellanes, J, Bravo A, Lamilla J, Sepúlveda J, Vögler 479 R, Guerrero Y, Bustamante C, Alarcón MA, Queirolo D, Hurtado F, Gaete E, Rojas P, 480 Montenegro I, Escobar R, Zamora V. 2007. Caracterización del fondo marino entre la III y X 481 Regiones (Informe Final FIP 2005-61). Valparaíso: Pontificia Universidad Católica de 482 Valparaíso. Available at http://www.fip.cl/Proyectos.aspx (accessed 25 February 2014). 
483 Menares B, Sepúlveda JT. 2005. Grupos recurrentes de peces y crustáceos demersales en la zona 484 centro-sur de Chile. Investigaciones Marinas, Valparaíso 33:91-100 DOI 10.4067/s071748571782005000100006.

486 Navia AF, Cortés E, Jordán F, Cruz-Escalona VH, Mejía-Falla PA. 2011. Changes to Marine 487 Trophic Networks Caused by Fishing. In: Mahamane A, ed. Diversity of Ecosystems. Croatia: 488 InTech Press, 418-452 DOI 10.5772/37787

489 Ojeda P. 1983. Distribución latitudinal y batimétrica de la ictiofauna demersal del extremo austral 490 de Chile. Revista Chilena de Historia Natural 56:61-70.

491 Ojeda FP, Labra FA, Muñoz AA. 2000. Biogeographic patterns of Chilean littoral fishes. Revista 492 Chilena de Historia Natural 73:625-641.

493 Pakhomov EA, Bushula T, Kaehler S, Watkins BP, Leslie RW. 2006. Structure and distribution of 494 the slope fish community in the vicinity of the sub-Antarctic Prince Edward Archipelago. 495 Journal of Fish Biology 68:1834-1866 DOI 10.1111/j.1095-8649.2006.01076.x

496 Pequeño G. 1989. Peces de Chile. Lista sistemática revisada y comentada. Revista de Biología 497 Marina, Valparaíso 24:1-132.

498 Pequeño G. 2000. Delimitaciones y relaciones biogeográficas de los peces del Pacifico 499 suroriental. Estudios Oceanologicos 19:53-76.

500 Pequeño G, Lamilla J. 1993. Batoideos comunes a las costas de Chile y Argentina-Uruguay 501 (Pises: Chondrichthyes). Revista de Biología Marina, Valparaíso 28:203-217.

502 Pequeño G, Rucabado J, Lloris D. 1990. Tiburones comunes a las costas de Chile, California503 Oregon y Namibia-Sud África. Revista de Biología Marina, Valparaíso 25:65-80.

504 Priede IG, Froese R, Bailey DM, Bergstad OA, Collins MA, Dyb JA, Henriques C, Jones EG, 505 King K. 2006. The absence of sharks from abyssal regions of the world's oceans. Proceedings 506 of the Royal Society B 273:1435-1441 DOI 10.1098/rspb.2005.3461 
507 Rex MA, Stuart CT, Coyne G. 2000. Latitudinal gradients of species richness in the deep-sea

508 benthos of the North Atlantic. Proceedings of the National Academy of Sciences of the United

$509 \quad$ States of America 97:4082-4085 DOI 10.1073/pnas.050589497

510 Rohde K. 1992. MINI- Latitudinal gradients in species diversity: the search for the primary 511 cause. Oikos 65:514-527.

512 Sellanes J, Quiroga E, Neira C, Gutiérrez D. 2007. Changes of macrobenthos composition under

513 different ENSO conditions on the continental shelf off central Chile. Continental Shelf

514 Research 27:1002-1016 DOI 10.1016/j.csr.2007.01.001

515 Shepherd TD, Myers RA. 2005. Direct and indirect fishery effects on small coastal 516 elasmobranchs in the northern Gulf of Mexico. Ecology Letters 8:1095-1104 DOI $517 \quad 10.1111 / \mathrm{j} .1461-0248.2005 .00807 . \mathrm{x}$

518 Sielfeld W, Vargas M. 1999. Review of marine fish zoogeography of Chilean Patagonia (42 $-57^{\circ}$ 519 S). Scientia Marina 63:451-463 DOI 10.3989/scimar.1999.63s1451

520 Spellerberg IF, Fedor PJ. 2003. A tribute to Claude Shannon (1916-2001) and a plea for more 521 rigorous use of species richness, species diversity and the 'Shannon-Wiener' Index. Global 522 Ecology and Biogeography 12:177-179 DOI 10.1046/j.1466-822X.2003.00015.x

523 Solervicens J. 1973. Coleópteros del bosque de Quintero. Anales del Museo de Historia Natural 524 de Valparaíso 6:115-159.

525 Wetherbee BM, Cortés E. 2004. Food consumption and feeding habits. In: Carrier JC, Musick 526 JA, Heithaus MR, eds. Biology of Sharks and Their Relatives. Boca Raton, FL: CRC Press, $527 \quad 223-244$.

528 Wolff M, Aroca T. 1995. Population dynamics and fishery of the Chilean squat lobster 529 Cervimunida johni Porter (Decapoda, Galatheidae) off the coast of Coquimbo, Northern Chile. 530 Revista de Biología Marina, Valparaíso 30:57-60. 


\section{Figure 1}

study area

Map of (A) Chile showing location of study area (inset box) and (B) location of zones (Z1 to Z8) and sampling sites (circles). Commercial trawl intensity is indicated in (B), in terms of tows per nautical mile (nmi). Modified after Melo et al. (2007). 


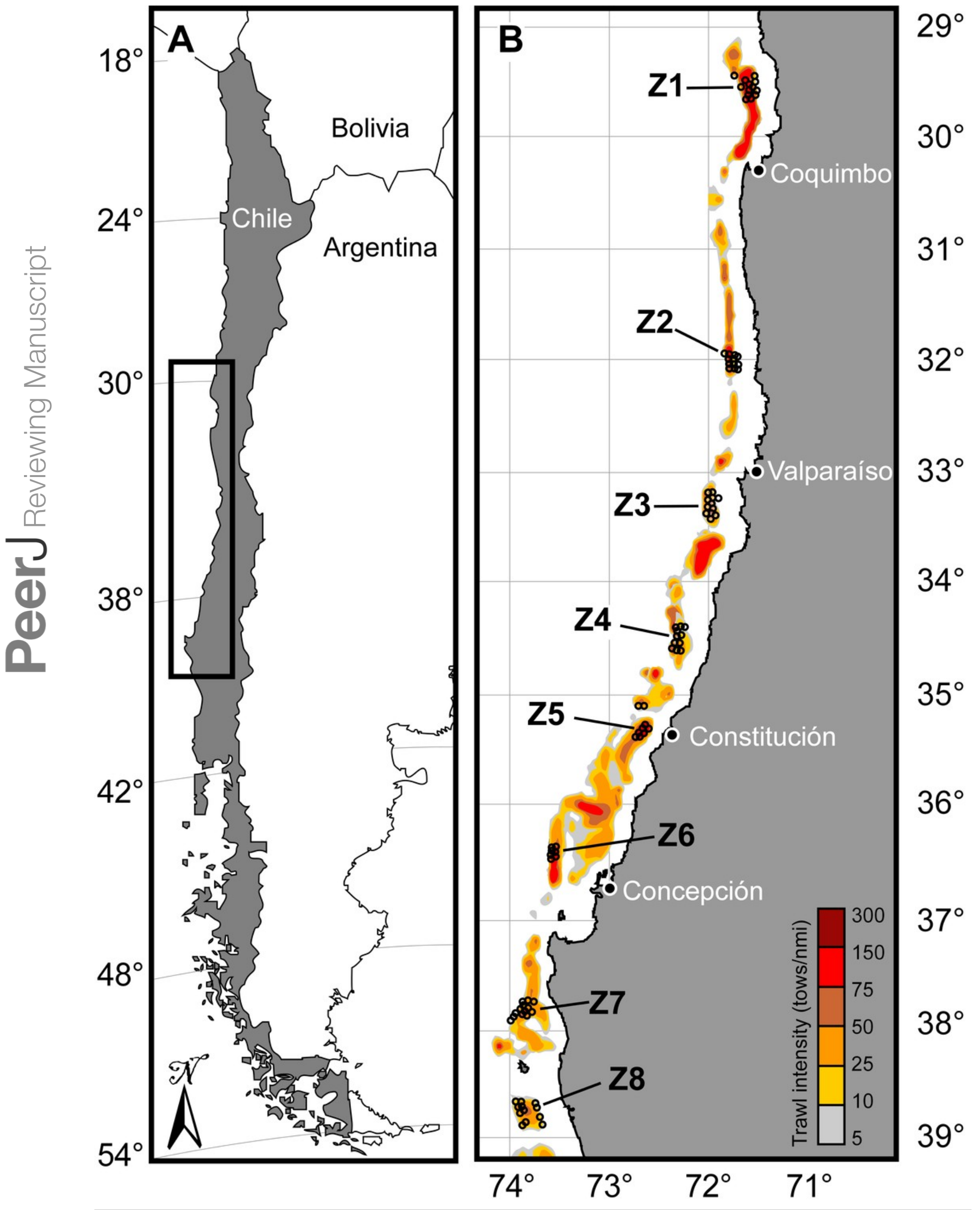




\section{Figure 2}

Variation of species richness in cartilaginous fishes.

Latitudinal and bathymetric changes of species richness of sharks $(A-B)$, skates $(C-D)$ and chimaeras (E-F) across the study area. Fitted least-square regression model (solid line) and statistical significance are indicated in each case.

Sharks

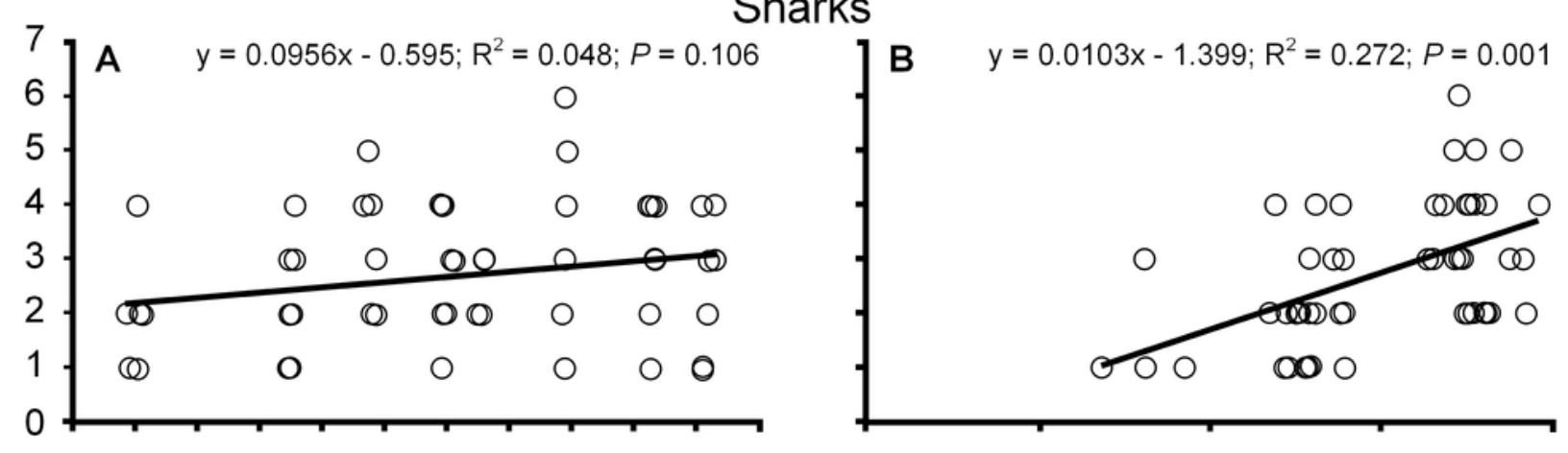

Skates
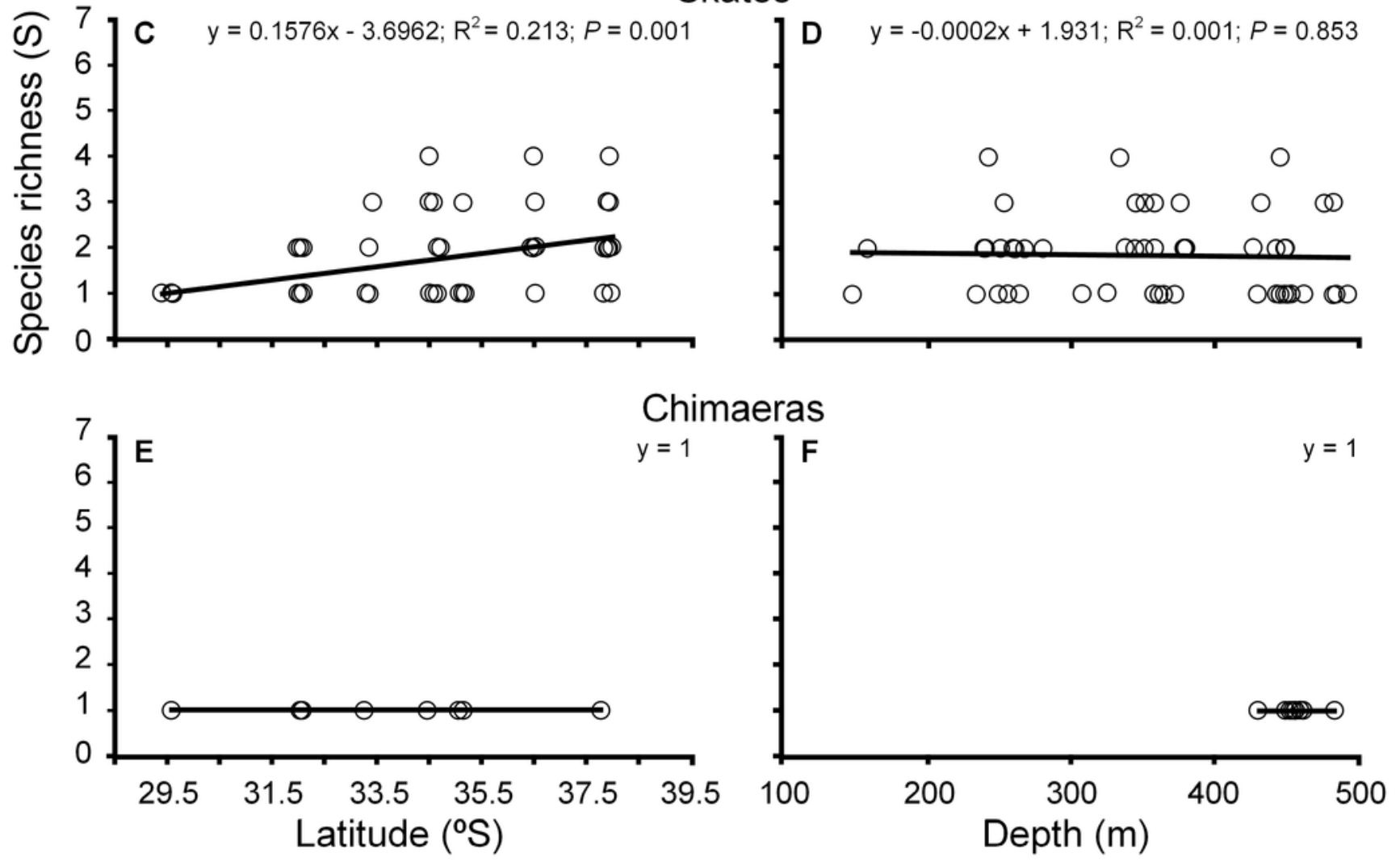


\section{Figure 3}

Variation in abundance of cartilaginous fishes in Chile.

Latitudinal and bathymetric changes of relative abundance (Log (CPUE+1)) of sharks (A-B), skates $(C-D)$ and chimaeras $(E-F)$ across the study area. Fitted least-square regression model (solid line) and statistical significance are indicated in each case.

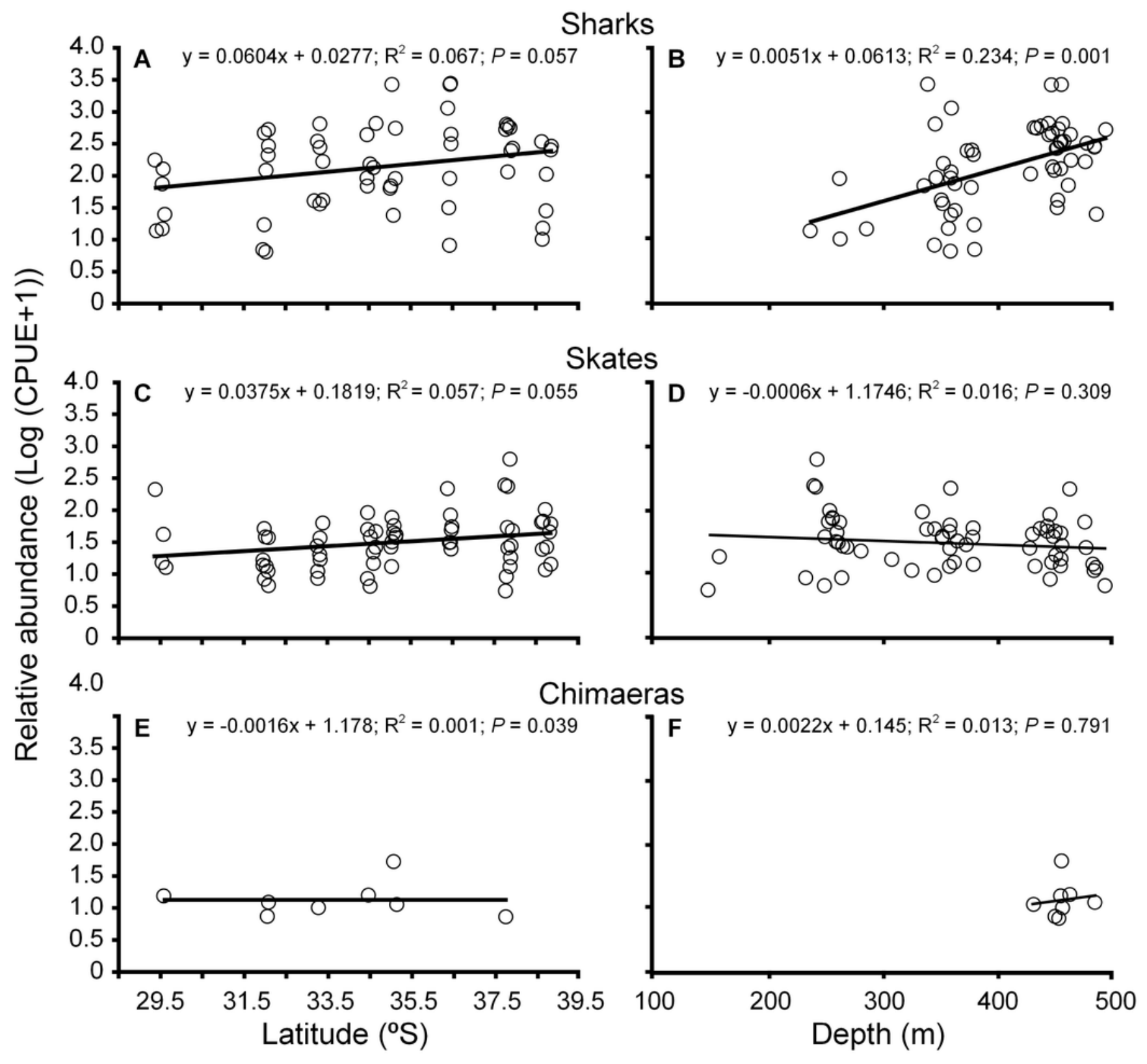




\section{Figure 4}

Variation in diversity of cartilaginous fishes in Chile.

Latitudinal and bathymetric changes of Shannon diversity index $(H)$ of sharks $(A-B)$ and skates (C-D) across the study area. Fitted least-square regression model (solid line) and statistical significance are indicated in each case.

Sharks

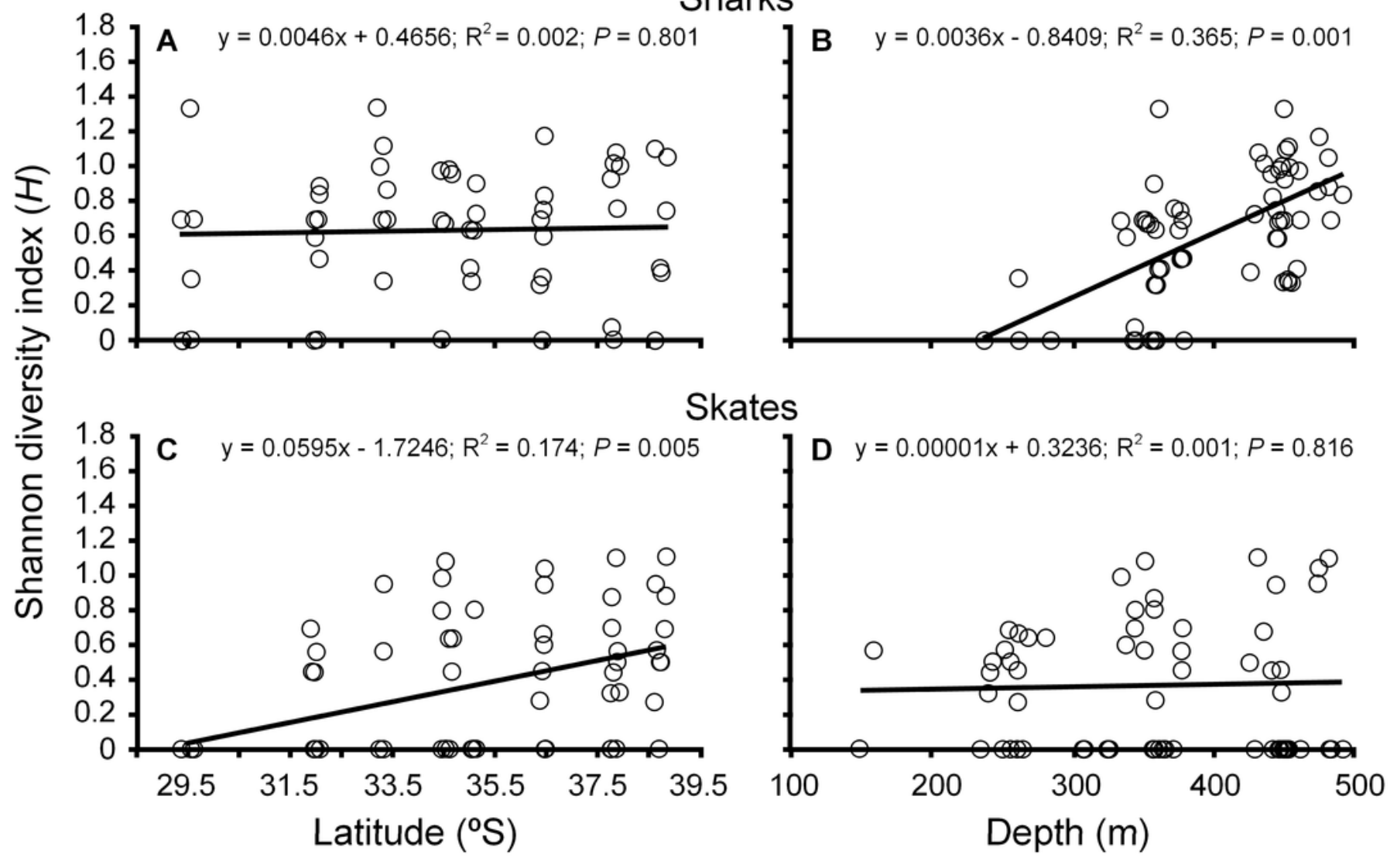




\section{Figure 5}

\section{Cluster of assemblages}

Agglomerative hierarchical cluster indicating the clustering of the four assemblages. Site grouping is colour coded and indicates $40 \%$ similarity. Sites are coded following zone (1 to 8), depth strata (A to D) and pseudoreplica (1 to 4).

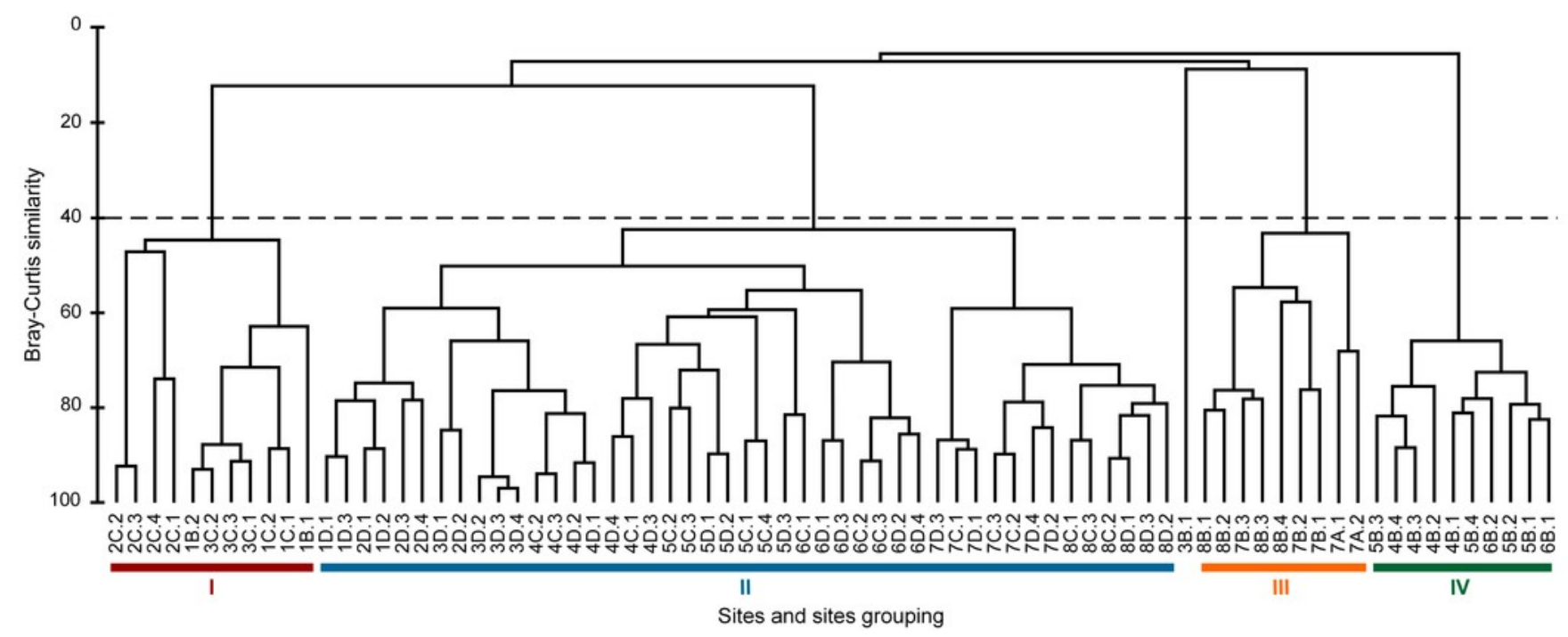




\section{Figure 6}

nMDS of sites.

Ordination in two-dimensions using non-dimensional metric scaling indicating the clustering of the four assemblages. Sites grouping is colour coded and indicate $40 \%$ similarity. Colour and site codes follows Fig. 5 .

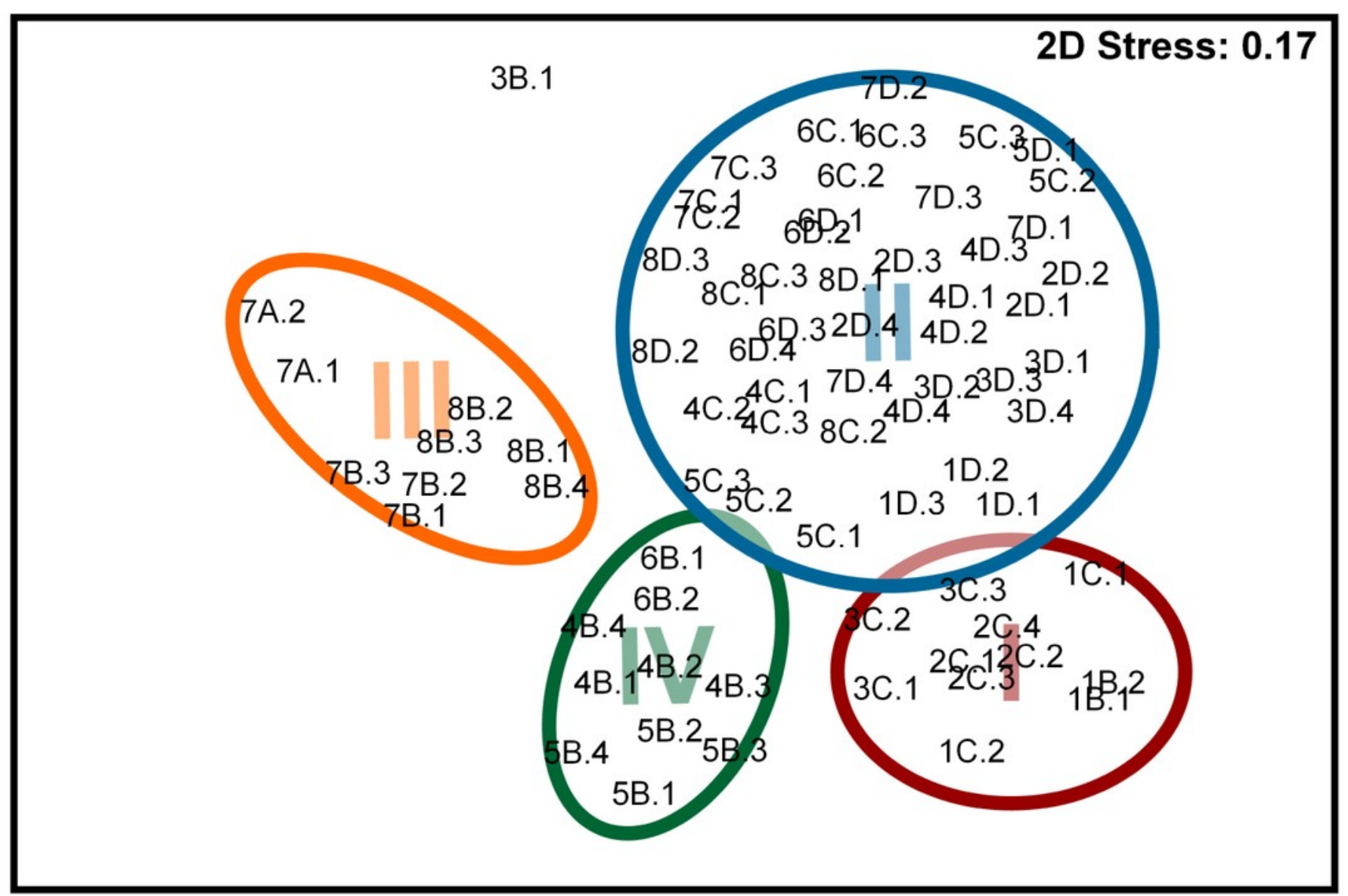




\section{Figure 7}

Diagram of abundance and latitudinal range of cartilaginous fishes in Chile.

Latitudinal distribution and abundance ( $\log (\mathrm{CPUE}+1))$ of cartilaginous fishes present in the continental shelf and slope of Chile. Solid lines represent species range reported by Acuña et al. (2005). 
Centroscymnus crepidater Echinorhinus cookei Centroscymnus owstoni Etpmopterus granulosus Schroederichthys chilensis Mustelus mento Hexanchus griseus Aculeola nigra

Centroscymnus macracanthus Centroscyllium granulatum Centroscyllium nigrum Deania calcea Apristurus brunneus Apristurus nasutus

Bythalelurus canescens

Hydrolagus macrophtalmus

Bathyraja albomaculata

Bathyraja brachyurops

Bathyraja multispinis

Bathyraja peruana

Psammobatis rudis

Gurgesiella furvescens Zearaja chilensis

Dipturus trachyderma

Rajella sadowsky

Torpedo tremens

Psammobatis scobina
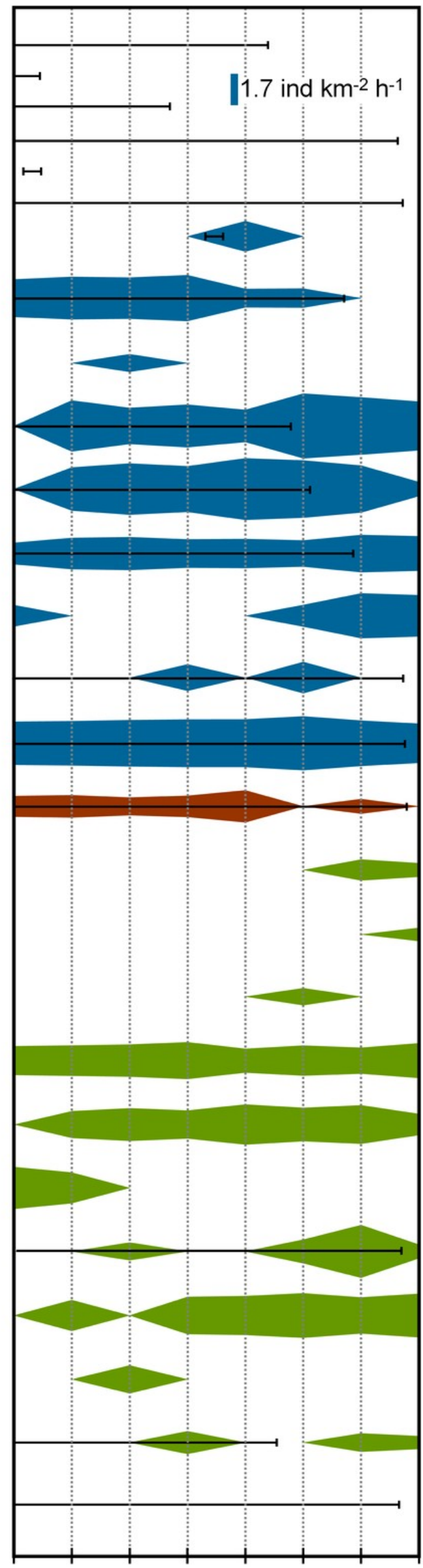

29.532 .033 .234 .535 .136 .437 .838 .7

PeerJ reviewing PDF | (v2014:03:1807:1:0:NEW 7 May 2014titude $\left({ }^{\circ} \mathrm{S}\right)$ 


\section{Table 1 (on next page)}

Taxonomic composition of samples analysed.

Depth and latitudinal range of cartilaginous fishes caught during surveys. 


\begin{tabular}{|c|c|c|c|c|}
\hline Order & Family & Species & Depth range (m) & Latitudinal range $\left({ }^{\circ} \mathrm{S}\right)$ \\
\hline Hexanchiformes & Hexanchidae & Hexanchus griseus (Bonnaterre 1788) & $358-376$ & $35-35.1$ \\
\hline Squaliformes & Somniosidae & Centroscymnus macracanthus Regan 1906 & 455 & 33.3 \\
\hline Squaliformes & Etmopteridae & Centroscyllium nigrum Garman 1899 & $335-455$ & $32-38.8$ \\
\hline Squaliformes & Centrophoridae & Deania calcea (Lowe 1839) & $362-492$ & $29.5-38.9$ \\
\hline Carcharhiniformes & Scylio מైinidae & Apristurus brunneus (Gilbert 1892) & $443-461$ & $34.5-36.5$ \\
\hline Carcharhiniformes & Scylio & Bythaelurus canescens (Günther 1878) & $237-492$ & $29.4-38.9$ \\
\hline Rajiformes & Arhynghobatidae & Bathyraja albomaculata (Norman 1937) & $356-436$ & $37.8-38.7$ \\
\hline Rajiformes & Arhynchobatidae & Bathyraja brachyurops (Fowler 1910) & 482 & 38.9 \\
\hline Rajiformes & Arhynchobatidae & Bathyraja multispinis (Norman 1937) & 445 & 36.4 \\
\hline Rajiformes & Arhy 1 hobatidae & Bathyraja peruana McEachran \& Miyake 1984 & $243-492$ & $29.6-38.9$ \\
\hline Rajiformes & Arhy Whobatidae & Psammobatis rudis Günther 1870 & $240-475$ & $32-38.8$ \\
\hline Rajiformes & Rajidae & Rajella sadowskii (Krefft \& Stehmann 1974) & 475 & 33.4 \\
\hline Rajiformes & Torpedinidae & Torpedo tremens de Buen 1959 & $149-376$ & $34.5-38.9$ \\
\hline Chimaeriformes & Chimaeridae & Hydrolagus macrophthalmus de Buen 1959 & $430-483$ & $29.6-37.8$ \\
\hline
\end{tabular}




\section{Table 2 (on next page)}

Summary of the sampling design

Percentage of tows with cartilaginous fishes in the catch, species richness (S) and total number $(\mathrm{N})$ of cartilaginous fishes caught in each zone and depth stratum. 


\begin{tabular}{crrr}
\hline Zone & Catch $(\%)$ & $\mathbf{S}$ & $\mathbf{N}$ \\
\hline 1 & 37.5 & 7 & 2,921 \\
2 & 56.25 & 10 & 14,871 \\
3 & 56.25 & 11 & 12,199 \\
4 & 62.5 & 11 & 15,058 \\
5 & 68.75 & 10 & 23,224 \\
6 & 56.25 & 12 & 60,651 \\
7 & 75 & 12 & 47,862 \\
8 & 62.5 & 12 & 17,919 \\
\hline
\end{tabular}

\begin{tabular}{crrr}
\hline Depth stratum (m) & Catch (\%) & \multicolumn{1}{c}{ S } & $\mathbf{N}$ \\
\hline $100-200$ & 3.13 & 2 & 203 \\
$200-300$ & 65.63 & 8 & 18,907 \\
$300-400$ & 78.13 & 14 & 58,597 \\
$400-500$ & 90.63 & 18 & 116,998 \\
\hline
\end{tabular}




\section{Table 3 (on next page)}

Catch per unit effort of shark, skates and chimaeras per geographic zone.

Abundance, as total CPUE (ind km-2 $\mathrm{h}^{-1}$ ) of cartilaginous fishes caught during surveys in each zone (geographic location of zones is indicated in Fig. 1). 


\begin{tabular}{|c|c|c|c|c|c|c|c|c|}
\hline \multirow{2}{*}{ Species } & \multicolumn{8}{|c|}{ Zone } \\
\hline & 1 & 2 & 3 & 4 & 5 & 6 & 7 & 8 \\
\hline H. griseus & -- & -- & -- & -- & 54.7 & -- & -- & -- \\
\hline A. nigra & 130 & 249.4 & 208 & 390 & 10 & 11 & -- & -- \\
\hline C. macracanthus & -- & -- & 9.2 & -- & -- & -- & -- & -- \\
\hline C. granulatum & -- & 770.6 & 109.9 & 259.8 & 64.7 & 4,611 & 1,730 & 577.6 \\
\hline C. nigrum & -- & 257.5 & 752.6 & 363.8 & $2,845.1$ & $1,639.8$ & 435.7 & 5.2 \\
\hline D. calcea & 15 & 54.7 & 68.5 & 37.8 & 41.5 & 28.4 & 122.1 & 85.1 \\
\hline A. brunneus & 15 & -- & -- & -- & -- & 15.5 & 326.3 & 206.7 \\
\hline A. nasutus & -- & -- & -- & 30.6 & -- & 59.2 & -- & -- \\
\hline B. canescens & 272.7 & 312.5 & 403.8 & 476.5 & 483.2 & 1084.4 & 361.4 & 160.5 \\
\hline B. albomaculata & -- & -- & -- & -- & -- & -- & 14.5 & 5 \\
\hline B. brachyurops & -- & -- & -- & -- & -- & -- & -- & 4.7 \\
\hline B. multispinis & -- & -- & -- & -- & -- & 8.4 & -- & -- \\
\hline B. multispinis & 42.4 & 52 & 65.7 & 121.8 & 21.5 & 50.2 & 29 & 92 \\
\hline P. rudis & -- & 32.7 & 71.0 & 38.5 & 192.2 & 77.1 & 154.2 & 14.9 \\
\hline G. furvescens & 239.5 & 55.5 & -- & -- & -- & -- & -- & -- \\
\hline Z. chilensis & -- & -- & 9.2 & -- & -- & 21 & 984.1 & 5 \\
\hline D. trachyderma & -- & 55.8 & -- & 127.8 & 159.3 & 336.2 & 100.6 & 395.3 \\
\hline R. sadowskii & -- & -- & 38.2 & -- & -- & -- & -- & -- \\
\hline T. tremens & -- & -- & -- & 18.7 & -- & -- & 10.1 & 4.4 \\
\hline H. macrophthalmus & 14.2 & 17.6 & 9.2 & 15.2 & 63.9 & -- & 5.9 & -- \\
\hline Total & 728.8 & $1,858.3$ & $1,745.3$ & $1,880.5$ & $3,936.1$ & $7,942.2$ & $4,273.9$ & $1,556.4$ \\
\hline
\end{tabular}




\section{Table 4 (on next page)}

Occurrence of shark, skates and chimaeras per geographic zone.

Frequency of occurrence of cartilaginous fishes caught during surveys in each zone (geographic location of zones is indicated in Fig. 1). 


\begin{tabular}{|c|c|c|c|c|c|c|c|c|}
\hline \multirow{2}{*}{ Species } & \multicolumn{8}{|c|}{ Zone } \\
\hline & 1 & 2 & 3 & 4 & 5 & 6 & 7 & 8 \\
\hline H. griseus & -- & -- & -- & -- & 100 & -- & -- & - \\
\hline A. nigra & 7.2 & 27.6 & 20.1 & 43.2 & 0.8 & 1.2 & -- & - \\
\hline C. macracanthus & -- & -- & 100 & -- & -- & -- & -- & - \\
\hline C. granulatum & -- & 8.7 & 1.1 & 2.9 & 0.5 & 49.6 & 27.2 & 10 \\
\hline C. nigrum & -- & 4.6 & 11.8 & 6.5 & 37.7 & 28.2 & 10.9 & 0.1 \\
\hline D. calcea & 1.4 & 10.5 & 11.5 & 7.3 & 5.9 & 5.9 & 32.8 & 25.2 \\
\hline A. brunneus & 0.9 & -- & -- & -- & -- & 1.9 & 57.3 & 39.9 \\
\hline A. nasutus & -- & -- & -- & 35.2 & -- & 64.8 & -- & - \\
\hline B. canescens & 4 & 9.1 & 10.3 & 13.9 & 10.4 & 30.3 & 14.7 & 7.2 \\
\hline B. albomaculata & -- & -- & -- & -- & -- & -- & 72.6 & 27.4 \\
\hline B. brachyurops & -- & -- & -- & -- & -- & -- & -- & 100 \\
\hline B. multispinis & -- & -- & -- & -- & -- & 100 & -- & - \\
\hline B. peruana & 4.3 & 10.4 & 11.5 & 24.5 & 3.2 & 9.6 & 8.1 & 28.4 \\
\hline P. rudis & -- & 5.6 & 10.6 & 6.6 & 24.2 & 12.5 & 36.7 & 3.9 \\
\hline G. furvescens & 68.4 & 31.6 & -- & -- & -- & -- & -- & - \\
\hline Z. chilensis & -- & -- & 0.6 & -- & -- & 1.4 & 97.5 & 0.5 \\
\hline D. trachyderma & -- & 94.5 & -- & 10.4 & 9.5 & 26.1 & 12.6 & 36.9 \\
\hline R. sadowskii & -- & -- & 100 & -- & -- & -- & -- & - \\
\hline T. tremens & -- & -- & -- & 18.7 & -- & -- & 35.6 & 17 \\
\hline H. macrophthalmus & 6.9 & 17 & 7.7 & 14.8 & 45.6 & -- & 8 & - \\
\hline
\end{tabular}




\section{Table 5 (on next page)}

Catch per unit effort and occurrence of shark, skates and chimaeras per depth strata sampled.

Abundance, as total CPUE (ind km-2 $\left.\mathrm{h}^{-1}\right)$ and frequency of occurrence $\left(\mathrm{F}_{\mathrm{O}}\right)$ of cartilaginous fishes caught in each depth stratum $\dagger$ 


\begin{tabular}{|c|c|c|c|c|c|c|c|c|}
\hline \multirow{3}{*}{ Species } & \multicolumn{4}{|c|}{ CPUE } & \multicolumn{4}{|c|}{$\mathbf{F}_{\mathbf{O}}$} \\
\hline & \multicolumn{4}{|c|}{ Depth stratum } & \multicolumn{4}{|c|}{ Depth stratum } \\
\hline & $\mathbf{A}$ & B & C & D & $\mathbf{A}$ & B & $\mathbf{C}$ & D \\
\hline H. griseus & -- & -- & 54.7 & -- & -- & - & 100 & -- \\
\hline A. nigra & -- & 4.1 & 45.8 & 948.1 & -- & 0.4 & 4.6 & 95 \\
\hline C. macracanthus & -- & -- & -- & 9.2 & -- & -- & -- & 100 \\
\hline C. granulatum & -- & 85.4 & $3,258.8$ & $4,779.3$ & -- & 1.1 & 40.1 & 58.8 \\
\hline C. nigrum & -- & -- & $1,541.1$ & $4,758.6$ & -- & -- & 24.5 & 75.5 \\
\hline D. calcea & -- & -- & 220.9 & 232.3 & -- & -- & 48.7 & 51.3 \\
\hline A. brunneus & -- & -- & 23.2 & 540.2 & -- & -- & 4.1 & 95.9 \\
\hline A. nasutus & -- & -- & -- & 89.8 & -- & -- & -- & 100 \\
\hline B. canescens & -- & 18.7 & $1,121.4$ & $2,415.4$ & -- & 0.5 & 31.6 & 67.9 \\
\hline B. albomaculata & -- & -- & 9.4 & 10.0 & -- & -- & 48.4 & 51.6 \\
\hline B. brachyurops & -- & -- & -- & 4.7 & -- & -- & -- & 100 \\
\hline B. multispinis & -- & -- & -- & 8.4 & -- & -- & -- & 100 \\
\hline B. peruana & -- & 61.1 & 214.2 & 199.3 & -- & 12.9 & 45.1 & 42 \\
\hline P. rudis & -- & 430.1 & 122.4 & 28.1 & -- & 74.1 & 21.1 & 4.8 \\
\hline G. furvescens & -- & -- & 38.4 & 254.3 & -- & -- & 13.1 & 86.9 \\
\hline Z. chilensis & 13.7 & 951.1 & 39.9 & 14.5 & 1.3 & 93.3 & 3.9 & 1.4 \\
\hline D. trachyderma & -- & 375.4 & 431.2 & 278.5 & -- & 34.6 & 39.7 & 25.7 \\
\hline R. sadowskii & -- & -- & -- & 38.2 & -- & -- & -- & 100 \\
\hline T. tremens & 5.3 & 6.5 & 21.4 & -- & 16.1 & 19.6 & 64.3 & -- \\
\hline H. macrophthalmus & -- & -- & -- & 126.0 & -- & -- & -- & 100 \\
\hline Total & 19.0 & $1,932.4$ & $7,142.8$ & $14,734.9$ & & & & \\
\hline
\end{tabular}

$\dagger$ Depth strata are A: 100-199 m; B: 200-299 m; C: 300-399; D: 400-499. 


\section{Table 6 (on next page)}

SIMPER summary.

Average abundance (ind $\mathrm{km}^{-2} \mathrm{~h}^{-1}$ ) and percentage of contribution per species in each assemblage ( $n$ indicates the number of sites included per assemblage). 


\begin{tabular}{lrrrrrrrrr}
\hline \multirow{2}{*}{ Species/Assemblage } & \multicolumn{2}{c}{ I } & \multicolumn{2}{c}{ II } & \multicolumn{2}{c}{ III } & \multicolumn{2}{c}{ IV } \\
& Avg. & \% & \multicolumn{1}{c}{ Avg. } & \% & Avg. & \% & Avg. & \% \\
\hline H. griseus & -- & -- & 1.2 & 0.3 & -- & -- & -- & -- \\
A. nigra & 4.1 & 7.2 & 21.1 & 4.4 & -- & -- & 0.4 & 1.0 \\
C. macracanthus & -- & -- & 0.2 & 0.0 & -- & -- & -- & -- \\
C. granulatum & -- & -- & 178.5 & 37.6 & 1.1 & 0.7 & 8.1 & 20.4 \\
C. nigrum & 19.3 & 34.3 & 135.3 & 28.5 & -- & -- & -- & -- \\
D. calcea & 1.4 & 2.4 & 9.7 & 2.0 & -- & -- & -- & -- \\
A. brunneus & 1.4 & 2.4 & 12.2 & 2.6 & -- & -- & -- & -- \\
A. nasutus & -- & -- & 2.0 & 0.4 & -- & -- & -- & -- \\
B. canescens & 12.5 & 22.2 & 75.9 & 16.0 & -- & -- & -- & -- \\
\hline B. albomaculata & -- & -- & 0.4 & 0.1 & -- & -- & -- & -- \\
B. brachyurops & -- & -- & 0.1 & 0.0 & -- & -- & -- & -- \\
B. multispinis & -- & -- & 0.2 & 0.0 & -- & -- & -- & -- \\
B. peruana & 2.5 & 4.5 & 8.9 & 1.9 & 4.1 & 2.6 & -- & -- \\
P. rudis & 6.5 & 11.5 & 2.0 & 0.4 & 18.3 & 11.6 & 25.3 & 63.4 \\
G. furvescens & 2.8 & 4.9 & 5.9 & 1.2 & -- & -- & -- & -- \\
Z. chilensis & 0.8 & 1.5 & 1.2 & 0.3 & 106.2 & 67.4 & -- & -- \\
D. trachyderma & 5.1 & 9.0 & 16.3 & 3.4 & 26.8 & 17.0 & 5.7 & 14.2 \\
R. sadowskii & -- & -- & 0.8 & 0.2 & -- & -- & -- & -- \\
T. tremens & -- & -- & 0.5 & 0.1 & 1.1 & 0.7 & -- & -- \\
\hline H. macrophthalmus & -- & -- & 2.8 & 0.6 & -- & -- & -- & -- \\
\hline
\end{tabular}

